\title{
Effect of avandamet on conditioned food reflex in rats of different age groups
}

\author{
V.A. Gorbachenko, Zh.O. Kruchenko, E.A. Lukyanetz \\ O.O. Bogomoletz Institute of Physiology, NAS Ukraine, Kyiv; email: gva@biph.kiev.ua
}

\begin{abstract}
The prevalence of Alzheimer's disease (AD) is increasing in the absence of truly effective treatments. The recently discovered causal link between $A D$ and type 2 diabetes mellitus (T2DM) (non-insulin-dependent diabetes mellitus) suggests that an increase in insulin receptor resistance may affect brain aging and lead to $A D$. In our experiments, we tested Avandamet (AVD), the antidiabetic drug used for the treatment of T2DM, on temporary parameters of conditioning food reflex in rats. We measured the individual components of the sensorimotor reaction (SMR) of rats, which reflect CNS's functional state. Important tha 7t rosiglitazone is the main component of AVD. It acts by activating the nuclear peroxisome proliferator-activated receptor (PPAR) gamma. Our data showed that this drug influences the brain function of both young and old rats. It is proved that AVD affects the CNS of rats by increasing their excitability. Considering the obtained data from the point of view of $A D$, the time parameter, which changed more significantly in old rats, was responsible for analyzing the situation and speed of action. Under AVD's influence, old rats became more agile and had increased motor activity, also the success of rats in performing a conditioned reflex was increased. Thus, the drug AVD and its active component rosiglitazone can be perspective for its testing in AD treatment. Key words: Alzheimer's disease; avandamet; behavior; conditioning reflex; food reflex; rats; PPAR; rosiglitazone.
\end{abstract}

\section{INTRODUCTION}

It is known that Alzheimer's disease (AD) is an incurable disease in which the death of brain cells and the disruption of neural connections occur. The latter leads to the degradation of brain functions, and especially this concerns the loss of memory. In this case, drug therapy mitigates the manifestation of symptoms and reduces the rate of negative changes. However, it is impossible to pull through patients with AD at present.

Recently, the positive effect of drugs used totreattype 2 diabetes mellitus (T2DM) on AD patients has been described $[1,2]$. It was also reported that patients with T2DM increase the risk of $\mathrm{AD}$ [3]. Comparative efficacy and accept ability of antidiabetic agents for AD and mild cognitive impairment were also studied [4]. These findings indicated a pro-cognitive effect of antidiabetic agents in AD. In several laboratories, the effects of antiglycemic drugs were studied

(C) V.A. Gorbachenko, Zh.O. Kruchenko, E.A. Lukyanetz in disease models in rodents. Thus, the neuroprotective potential of antihyperglycemic drug metforminin a streptozocin-induced rat model of sporadic AD was studied [5]. These authors' results showed that metformin reversed in $\mathrm{AD}$ model-rats impairments in spatial learning/ memory performance and sociability. In other experiments, it was shown that the insulindegradingenzyme contributed to the pathology in a mixed model of T2DM and AD [6]. Recently, many data have appeared that deal with the problem of the relationship between AD and T2DM [1, 7-12].

Among such antidiabetic drugs that were tested in experiments with AD turned out rosiglitazone. Thus, recently, the rosiglitazone embedded nanocarrier system's neuroprotective potential was explored on the streptozotocininduced mice model of AD [13]Based on their results, the authors concluded that rosiglitazone nanoformulation exerts strong neuroprotection 
via increasing the mRNA expression of growth factors and inhibition of oxidative stress, neuroinflammation and eventually prevents neuronal injury in AD. It has also been shown that rosiglitazone improved hippocampusdependent cognition in the AD mouse model [14] Also, rosiglitazone prevents the memory deficits induced by amyloid-beta oligomers [15]

Therefore, our research aimed to study the effect of the antidiabetic drug rosiglitazone in the form of a medicinal product Avandamet (AVD), on memory processes in young and old rats. Old rats were used as a model of $\mathrm{AD}$ in our experiments. We applied an analysis of the conditioned food reflex's temporal characteristics in rats, so far as these reflect the efficiency of the brain activity.

\section{METHODS}

All experimental procedures were following the European Commission Directive (86/609/ EEC) and ethical guidelines of the International Association for the Study of Pain and were approved by the local Animal Ethics Committee of the O.O. Bogomoletz Institute of Physiology (Kyiv, Ukraine). All efforts were made to minimize the numbers and suffering of animals used. Experiments were carried out on female Wistar rats aged 3 and 15 months, weighing 180220 g. Rats were kept under standard vivarium conditions (temperature $23-25^{\circ} \mathrm{C}$ ). Animals were divided into control and experimental groups of young and old ( $\mathrm{n}=5$ in each).

AVD (Rosiglitazone Maleateand Metformin $\mathrm{HCl}$ ) from Glaxo Smith Kline, Spain, was used. An a queous solution of AVD was administered at a dose of $4 \mathrm{mg} / \mathrm{kg}$ per os for $1 \mathrm{~h}$ before the experiment.

The conditioned food reflex was formed in an automated experimental chamber (automated device), which consisted of a main $(30 \times 25 \times$ $25 \mathrm{~cm})$ and food $(15 \times 25 \times 25 \mathrm{~cm})$ compartments, between which there was a transparent wall with a closing hole for access to arotating auto-feeder with food balls. On the front wall of the main compartment at the top was the source of the conditional sound signal (60 Db). After three days of adaptation (habituation of the animal to the experimental chamber), the animals were placed in the main compartment on the fourth day. After turning on the conditioned signal, the food compartment window was opened for $5 \mathrm{~s}$, and the animal was allowed to move freely. In the case of approaching the feeder with a signal, the rat received food. One experiment included 10 samples, separated by $60 \mathrm{~s}$ intervals. During testing, the number of correct responses (the level of differentiation), the food-procuring reaction duration, and its components were assessed.

We used the automated device and software developed by ourselves [16, 17], to register the individual components of sensorimotor reaction (SMR). The principle of the behavior registrations based on the operation of infrared sensors registered the moving rats' paw in the hole of the feeding chamber.

In the rats placed in the main box, the skill, in response to a short sound, was developed to make search movements with a limb in an empty feeder, reinforced after $2 \mathrm{~s}$ by feeding. The interval between the individual presentations of the sound was the $30 \mathrm{~s}$. The time course of the experiment and corresponding time indicators were registered. Using this system and software, we registered and analyzed following SMR indicators: $t l$ - latent period, the time before the first the attempt of getting food after the sound stimulus; $r t$ - limb staying in the food window before supplying the food; $R D$-the mean time of the limb staying in the food cell during the single attempt of obtaining the food; $T R r$-the mean time between the attempts of obtaining the food; $R N$ - the number of required attempts for getting food; $R T$ - a mean time for motor response of obtaining food: total time of getting food from the feeder. In addition to these indicators, were corded the number of successful responses expressed as a percentage of the total number of audio stimulus and RNIS -number of approaches to the food window position between the sound signals during the interstimulus period (ISP). 
These time parameters characterize the speed of information processing in the CNS, the level of motivation, and the animal's overall excitability.

Data are presented as means \pm standard error (s.e.). The statistical significance of differences between the values in control and treated groups were estimated using a Student's t-test; the cases with $\mathrm{P}<0,05$ were considered to be statistically significant.

\section{RESULTS}

During testing the food-getting reflex, we found that success in getting food was better in young rats. In the control group, the success of the conditioned reflex's manifestations in young rats was higher $(91.6 \%$; Fig. 1A) than in older ones $(84.27 \%$; Fig. 1B). In the older group, we observed greater variation of this indicator that may be due to age-related difficulties in the extraction of information about conditioning stimuli. AVD increased the
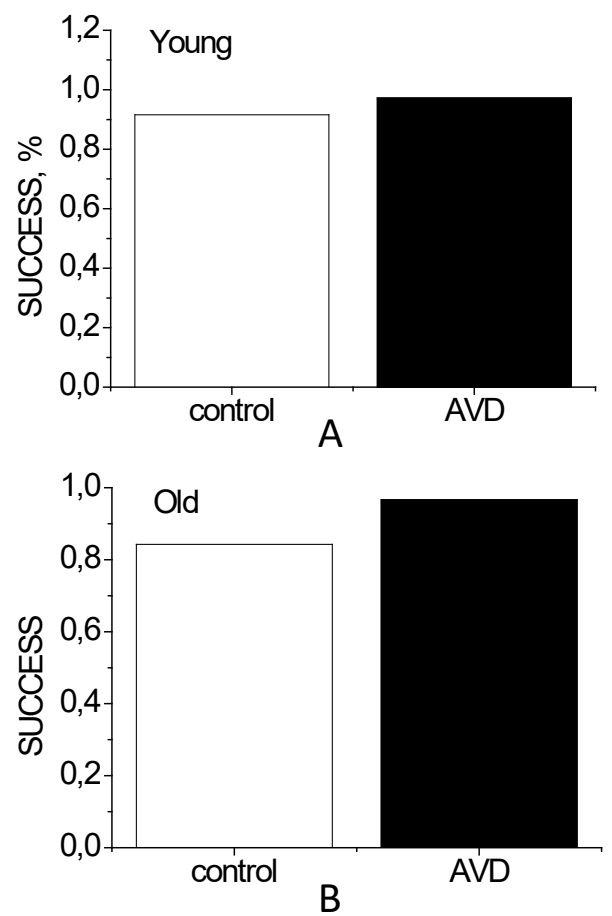

Fig. 1. The mean data of registration of successfulness of conditional food reflex (rat obtaining of feed after sound) measured in control conditions (white) and in rats that consumed AVD (black). Tests performed on young (A) and old (B) rats success of manifestations of the conditioned reflex in old rats to young group indicators registered in control $(96.67 \%)$ Fig. 1B. At the same time, this parameter achieved $97.28 \%$ in young rats after AVD treatment, Fig. 1A. Thus, AVD substantially improved the success of the manifestations of the conditioned reflex in both age groups. The high success rate of the reflex (over 90\%) may be the result of several factors: on the one hand - a reason ably strong link between the representations of the sensory and motor zone sin the CNS, on the other - high food motivation. But, as already mentioned, since all animals were in the same conditions of food deprivation, the growth of the excitatory process was caused by the action of the AVD.

We determined that while AVD did not affect the number of attempts required to pull food out of the food window (RN), this drug significantly increased the number of approaches to the trough window (RNIS) in both rats' groups (Fig. 2). Thus, AVD increased the value RNIS - the number of animal approaches to the food window position between the sound signals during the inter stimulus period. RNIS was increased by $68,63 \%$ in young (Fig. 2A) and $49,56 \%$ in old animals (Fig. 2B). In young animals, the values differed statistically significantly. It should be noted that the value of RNIS was significantly higher in young rats than in old ones in control conditions. Thus, in old rats, RNIS was 4.96, while in young rats, it was almost twice as much - 9.24. These experiments have shown that AVD enhances the CNS excitatory process, as evidenced by the increase in the number of interstimulus reactions in both young and old rats.

Testing the conditioned reflex's temporal characteristics showed that in control experiments in young animals, the time of search movements $(r t)$ in an empty feeder after the conditional sound signal was twice as long as in old ones (Fig. 3). The latter can be explained by the higher degree of CNS excitability characteristic of early life, rather than the high degree of food motivation, as rats of both age groups were previously on 24-hour food-deprived. AVD 
did not affect $r t$ temporal characteristics in two groups of animals (Fig. 3A, B).

After treatment with AVD, the time between individual food extraction movements (TRr) and the total time spent on extracting food balls from the feeder (RT) was decreased (Fig. 3). Thus, in young rats, the value of $T R r$ decreased by an average of $248 \mathrm{~ms}$, and in old rats by 96 $\mathrm{ms}$, which was 34.24 and $15.95 \%(\mathrm{n}=143)$, respectively, relative to the control values. It should be noted that the changes in values were statistically significant in young animals.

Regarding $R T$ value, it proved This value was found to be higher in young rats than in old in control conditions. This manifestation can be explained by the fact of the low level of CNS excitation in old rats compared with young promotes a more accurate motor response both in control (1592 $\mathrm{ms}$ in the old, $2040 \mathrm{~ms}$ in the
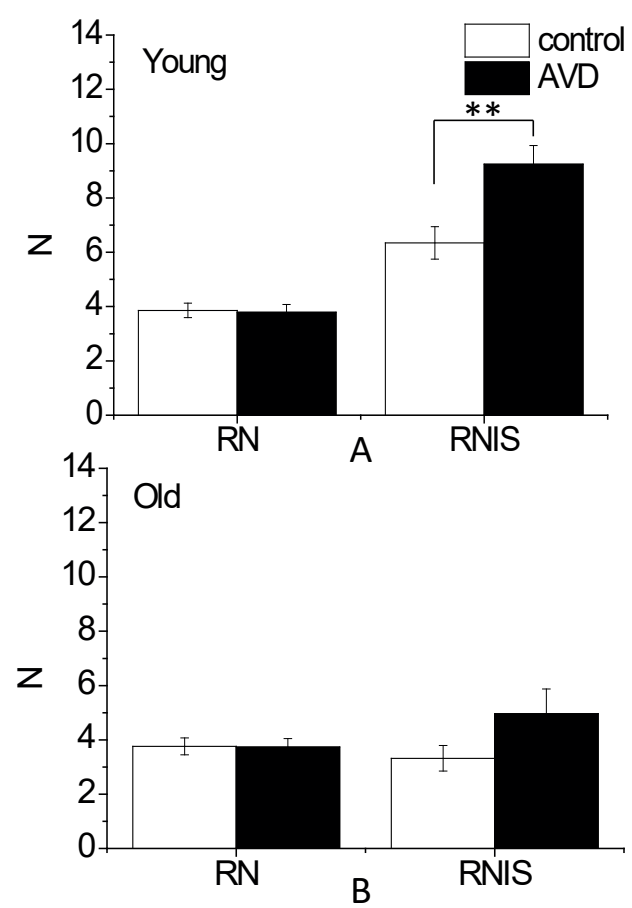

Fig. 2. The average values of the quantitative characteristics of rat food reflex recorded in control and under treatment with AVD in young (A) and old rats (B) are presented. The valuesare $R N$ - the number of required attempts for getting food and RNIS - number of approaches to the food window position between the sound signals during the interstimulus period. The significance of the differences with $P<0,01$ is indicated by two asterisk young) and under the influence of AVD (1363 ms in the elderly, $1741 \mathrm{~ms}$ in young) and is not due to a high level of food motivation. The time $R T$ decreased in young rats under AVD's influence on average by $299 \mathrm{~ms}$, in old by $229 \mathrm{~ms}$, which was $14.7 \%$ and $14.4 \%(n=143)$ of the control value, respectively (Fig. 3A,B).

In old rats, AVD also caused a decrease in $R D$ value by an average of $133 \mathrm{~ms}(\mathrm{n}=143)$ ( $15.95 \%$ of control), whereas, in young animals, this temporal characteristic was changed not significantly. This parameter is responsible for the time the animal's limb is in the food hole during food retrieval.

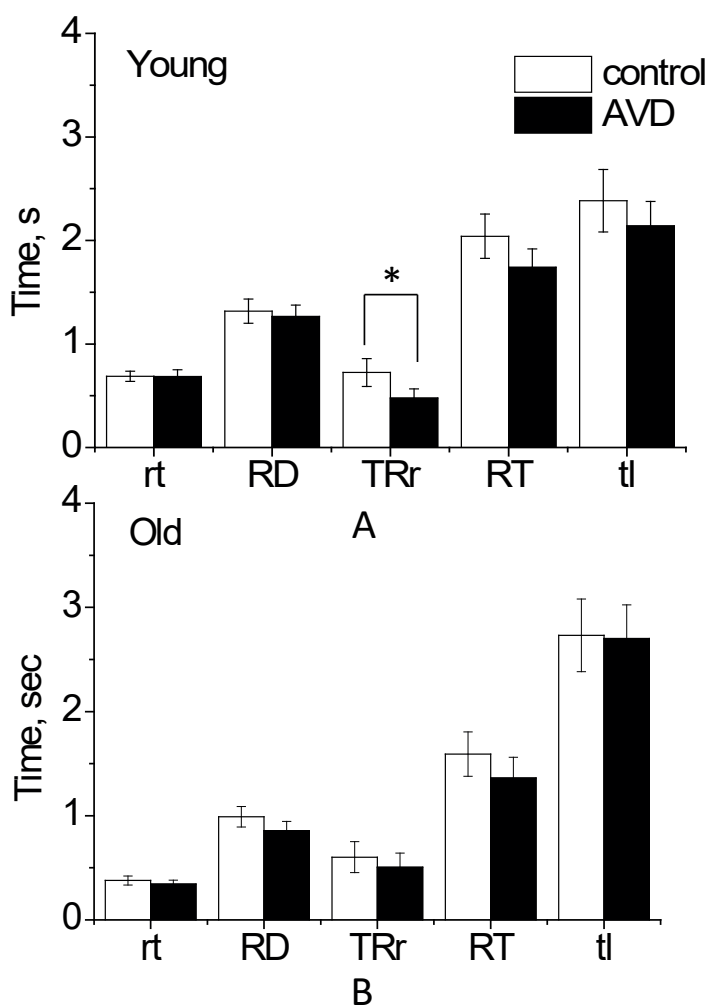

Fig. 3. The average values of temporal characteristics of rat food reflex recorded in control and after treatment with AVD in young (A) and old (B) rats. The values are $r t-$ limb staying in the food window before supplying the food, $R D$ - the mean time of the limb staying in the food cell during the single attempt of obtaining the food, $T R r$ - the mean time between the attempts of obtaining the food, $R T$ - total time of getting food from the feeder, $t l$ - latent period, the time before the first the attempt of getting food after the sound stimulus. The significance of the differences with $\mathrm{P}<0,05$ is indicated by one asterisk 
The latent period of the sensorimotor response $(t l)$ to the conditioned sound stimulus in control was more prolong in old animals than young groups (Fig. 3A, B). But AVD increased the speed of processing audio information by young animals on average by $243 \mathrm{~ms}(\mathrm{n}=143$, $10.2 \%$ of control). In old rats, it was not changed under the influence of AVD (Fig. 3B).

\section{DISCUSSION}

Currently, there are several hypotheses regarding the causes of Alzheimer's disease. Among them are the acetylcholine, mitochondrial, betaamyloid, calcium hypothesis, etc. But sometimes it is very difficult to understand which process is the cause and which is the consequence of the pathological changes. The latter also applies to AD. Our previous researches have addressed some aspects of this problem. In our previous experiments, we have shown that mitochondria , $\mathrm{K}^{+}$ion channels of mitochondria are subject to changes in AD modeling $[18,19]$. The role of calcium ions also has been shown $[20,21]$. We also tested the involvement of glutamate receptors in $\mathrm{AD}$ using the glutamate receptor antagonist memantine [22, 23]. Recently, a new hypothesis has appeared that AD may be associated with impaired glucose metabolism in the organism, with type 2 diabetes mellitus (T2DM) [1, 3, 7-12, 15,24].Important that the drugs used to treat T2DM has proven to be effective in correcting AD. One of these drugs is rosiglitazone, which is the main part of AVD. Just this compound we took in our experiments. To identify its action, we used the time parameters of the conditioned reflex in rats. These parameters quantitatively describe sensory-motor responses and make it possible to assess the central nervous system's functioning precisely. The old animals served as a model for $\mathrm{AD}$ in our experiments.

It would also like to say a few words about rosiglitazone. This compound works as an insulin sensitizer and is an agonist of the peroxisome proliferator-activated receptors
(PPARs). The receptors are the ligand-activated transcription factors of the nuclear hormone receptor superfamily, also known as the glitazone receptors. They comprised of three subtypes: PPAR $\alpha, \operatorname{PPAR} \beta / \delta$, and PPAR $\gamma$. Activation of PPAR- $\alpha$ reduces the triglyceride level and is involved in the regulation of energy homeostasis. Activation of PPAR- $\beta / \delta$ enhances fatty acids metabolism, whereas activation PPAR- $\gamma$ causes insulin sensitization and enhances glucose metabolism. Thus, nuclear receptors' PPAR family plays a major regulatory role in energy homeostasis and metabolic function [25].

The distribution of PPAR mRNA and protein in several brain regions was shown. Quantitative PCR and double immunofluorescence microscopy determined that both PPAR mRNA and protein are expressed ubiquitously throughout the adult mouse brain. PPARs regulate transcriptions through a complex mechanism as it is described in the review by Berger and Moller [26] and Nierenberg et al. [27].

Accordingly, receptors from this family, including PPAR- $\gamma$, are expressed in the brain and play a significant role in oxidative stress, energy homeostasis, mitochondrial fatty acids metabolism, and inflammation. Moreover, PPAR- $\alpha$ regulates expression of genes coding enzymes engaged in amyloid precursor protein (APP) metabolism. It activates gene coding of $\alpha$ secretase, which is responsible for the nonamyloidogenic pathway of APP degradation. It also down regulates $\beta$ secretase (BACE-1), the main enzyme responsible for amyloidbeta $(A \beta)$ peptide release in $A D$. It was shown that at $\mathrm{AD}$, the brain expression of genes of PPAR $-\alpha$ and PPAR $-\gamma$ is significantly decreased. Moreover, the expression of PPARs is altered not only in $\mathrm{AD}$ but in other neurodegenerative/ neurodevelopmental and psychiatric disorders.

Our experiments have shown that rosiglitazone, an agonist of PPAR- $\gamma$, and the main component of AVD, enhances the CNS excitatory process in both age groups. That is evidenced by the increase in the number of interstimulus reactions in both young and old rats. The high 
success rate of the reflex (over 90\%) in the case of AVD treatment may be the result of several factors: on the one hand - a reasonably strong link between the representations of the sensory and motor zones in the CNS, on the other - high food motivation. But, as already mentioned, since all animals were in the same conditions of food deprivation, the excitatory process's growth was caused by the action of the AVD.

Thereby, our data indicate that the antidiabetic drug AVD, which is used to treat T2DM (insulin-non-dependent diabetes mellitus), affects the CNS by increasing its excitability. Our data showed that this drug influences the brain function of both young and old rats. If we consider the obtained data from the point of view of $\mathrm{AD}$, the time parameter, which changed more significantly in old rats, was - $R D$, responsible for analyzing the situation and speed of action. Old rats became more agile and had increased motor activity under the influence of AVD. This compound also increased the success of rats in performing a conditioned reflex. Thus, the drug AVD may be recommended for its testing in AD treatment.

\section{CONCLUSIONS}

AVD at a dose of $4 \mathrm{mg} / \mathrm{kg}$ increases the CNS's excitability, manifested by the several following facts;

increasing the number of interstimulus motor reactions;

reducing the time of removing food balls from the feeder, i.e., increasing the speed of individual phases of food movements. This trend is manifested regardless of the high state of motor excitability in young animals in control;

increase in individuals in a group of older animals the probability of reflex manifestations (the ability to extract from the "memory cells" the significance of the sound signal, which triggers the sequence of food movements).

Acknowledgments. This study was supported by National Academy of Sciences of Ukraine
(NASU) SRN $0118 U 007344$ and NASU grant for the development of priority areas of research SRN $0120 U 001281$.

The authors of this study confirm that the research and publication of the results were not associated with any conflicts regarding commercial or financial relations, relations with organizations and/or individuals who may have been related to the study, and interrelations of co-authors of the article.

\section{В.А. Горбаченко, Ж.О. Крученк, О.О. Лук'янець}

\section{ВПЛИВ АВАНДАМЕТУ НА УМОВНИЙ ХАРЧОВИЙ РЕФЛЕКС У ЩУРІВ РІЗНИХ ВІКОВИХ ГРУП}

Інститут фізіологї ім. О.О. Богомольияя НАНУ, Київ, Україна, email: gva@biph.kiev.ua

Поширеність хвороби Альцгеймера (XА) зростає за відсутності дійсно ефективних методів лікування. Нещодавно виявлений причинно-наслідковий зв 'язок між ХА та цукровим діабетом 2-го типу (ЦДТ2, неінсулінозалежний цукровий діабет) свідчить про те, що підвищення стійкості до інсулінових рецепторів може вплинути на старіння мозку та призвести до ХА. В наших експериментах було протестовано авандамет, протидіабетичний препарат, що застосовується для лікування ЦДТ2, на часові параметри умовного харчового рефлексу у щурів. Вимірювались окремі компоненти сенсомоторної реакції (СМР) щурів, які відображають функціональний стан ЦНС. Важливо, що росиглітазон є основним компонентом авандамету. Він діє через активацію гама-рецепторів, що активуються проліфераторами пероксисом. Наші результати показали, що цей препарат впливає на роботу мозку як молодих, так і старих щурів. Виявилось, що авандамет впливає на ЦНС щурів, підвищуючи їх збудливість. Враховуючи отримані результати з точки зору ХА, часовий параметр, який помітно змінився у старих щурів, відповідав за аналіз ситуації та швидкість дії. Під впливом авандамету старі щури стали більш спритними і мали підвищену рухову активність, а також збільшився їх успіх у виконанні умовного рефлексу. Таким чином, цей препарат та його активний компонент росиглітазон можуть бути перспективними для тестування при лікуванні ХА.

Ключові слова: хвороба Альцгеймера; авандамет; поведінка; умовний рефлекс; харчовий рефлекс; щури; PPAR; росиглітазон. 
В.А. Горбаченко, Ж.А. Крученк, Е.А. Лукьянец

\section{ВЛИЯНИЕ АВАНДАМЕТА НА УСЛОВНЫЙ ПИЩЕВОЙ РЕФЛЕКС У КРЫС РАЗНЫХ ВОЗРАСТНЫХ ГРУПП}

Распространенность болезни Альцгеймера (БА) увеличивается в отсутствие действительно эффективных методов лечения. Недавно обнаруженная причинная связь между БА и сахарным диабетом 2 типа (СД2, инсулиннезависимый сахарный диабет) предполагает, что повышение резистентности к рецепторам инсулина может влиять на старение мозга и приводить к БА. В наших экспериментах тестировали авандамет, противодиабетический препарат, используемый для лечения СД2, на временные параметры условного пищевого рефлекса у крыс. Измерялись отдельные компоненты сенсомоторных реакций (СМР) крыс, которые отражают функциональное состояние ЦНС. Важно то, что росиглитазон является основным компонентом авандамета. Он действует путем активации гамма-рецепторов, активируемых пролифераторами пероксисом. Наши результаты показали, что этот препарат влияет на функцию мозга как молодых, так и старых крыс. Оказалось, что он влияет на ЦНС крыс, повышая их возбудимость. Если рассматривать полученные результаты с точки зрения БА, то временной параметр, более существенно изменившийся у старых крыс, отвечал за анализ ситуации и скорость действий. Под влиянием авадаметастарые крысы стали более подвижными, у них повысилась двигательная активность, а также повысилась успешность крыс при выполнении условного рефлекса. Таким образом, препарат авандамет и его активный компонент росиглитазон могут быть перспективными для тестирования при лечении БА.

Ключевые слова: болезнь Альцгеймера; авандамет; поведение; условный рефлекс; пищевой рефлекс; крысы; PPAR; росиглитазон.

\section{REFERENCES}

1. Akter K, Lanza EA, Martin SA, Myronyuk N, Rua M, Raffa RB. Diabetes mellitus and Alzheimer's disease: shared pathology and treatment? Br J Clin Pharmacol. 2011;71(3):365-76.

2. McIntyre RS, Soczynska JK, Lewis GF, MacQueen GM, Konarski JZ, Kennedy SH. Managing psychiatric disorders with antidiabetic agents: translational research and treatment opportunities. Expert Opinion Pharmacother. 2006;7(10):1305-21.

3. Janson J, Laedtke T, Parisi JE, O'Brien P, Petersen RC, Butler PC. Increased risk of type 2 diabetes in Alzheimer disease. Diabetes. 2004;53(2):474.

4. Cao B, Rosenblat JD, Brietzke E, Park C, Lee Y, Musial N, et al. Comparative efficacy and acceptability of antidiabetic agents for Alzheimer's disease and mild cognitive impairment: A systematic review and network meta-analysis. Diabetes, Obesity Metab. 2018;20(10):2467-71.

5. Pilipenko V, Narbute K, Pupure J, Langrate IK, Muceniece R, Kluša V. Neuroprotective potential of antihyperglycemic drug metformin in streptozocin-induced rat model of sporadic Alzheimer's disease. Eur J Pharmacol. 2020:173290.

6. Li H, Wu J, Zhu L, Sha L, Yang S, Wei J, et al. Insulin degrading enzyme contributes to the pathology in a mixed model of type 2 diabetes and Alzheimer's disease: possible mechanisms of IDE in T2D and AD. Biosci Reports. 2018;38(1).

7. de Nazareth AM. Type 2 diabetes mellitus in the pathophysiology of Alzheimer's disease. Dement Neuropsychol. 2017;11(2):105-13.

8. Tumminia A, Vinciguerra F, Parisi M, Frittitta L. Type 2 diabetes mellitus and Alzheimer's disease: Role of insulin signalling and therapeutic implications. Int J Mol Sci. 2018;19(11):3306.

9. Mittal K, Katare DP. Shared links between type 2 diabetes mellitus and Alzheimer's disease: A review. Diabetes Metablic Syndrome: Clinical Research \& Reviews. 2016;10(2, Suppl 1):S144-S9.

10. Chatterjee S, Mudher A. Alzheimer's disease and type 2 diabetes: A critical assessment of the shared pathological traits. Front Neurosci. 2018;12:383.

11. Caberlotto L, Nguyen TP, Lauria M, Priami C, Rimondini $\mathrm{R}$, Maioli S, et al. Cross-disease analysis of Alzheimer's disease and type-2 diabetes highlights the role of autophagy in the pathophysiology of two highly comorbid diseases. Sci Reports. 2019;9(1):3965.

12. Kamal MA, Priyamvada S, Anbazhagan AN, Jabir NR, Tabrez S, Greig NH. Linking Alzheimer's disease and type 2 diabetes mellitus via aberrant insulin signaling and inflammation. CNS Neurol Disord Drug Targets. 2014;13(2):338-46.

13. Sarathlal K CS, Kakoty V, Marathe S, Chitkara D, Taliyan R. Exploring the neuroprotective potential of rosiglitazone embedded nanocarrier system on streptozotocin induced mice model of Alzheimer's disease. Neurotoxic Res. 2020.

14. Denner LA, Rodriguez-Rivera J, Haidacher SJ, Jahrling JB, Carmical JR, Hernandez CM, et al. Cognitive enhancement with rosiglitazone links the hippocampal PPAR $\gamma$ and ERK MAPK signaling pathways. J Neurosci: the official journal of the Society for Neuroscience. 2012;32(47):16725-35a.

15. Xu S, Guan Q, Wang C, Wei X, Chen X, Zheng B, et al. Rosiglitazone prevents the memory deficits induced by amyloid-beta oligomers via inhibition of inflammatory responses. Neurosci Lett. 2014;578:7-11.

16. Gorbachenko V, Chereda I, Vrublevsky S, Kruchenko J, Lukyanetz E. Development and testing of the experimental system for registration of food reflex in rats. Bull Taras Shevchenko Natl Univ Kyiv Ser: Radiophysics and Electronics. 2014;1/2(21/22):31-3.

17. Gorbachenko VA, Kruchenko JO, Chereda IS, Lukyanetz 
EA. Measurements of the time parameters of conditioned food reflex in rats under memantin treatment with using of automatic registration system. Bull Taras Shevchenko Natl Univ KyivSer: Radiophysics and Electronics. 2015;1(23):23-6.

18. Kravenska EV, Ganzha VV, Yavorskaya EN, Lukyanetz EA. Effect of cyclosporin A on the viability of hippocampal cells cultured under conditions of modeling of Alzheimers disease. Neurophysiology. 2016;48(4):246-51.

19. Kravenska Y, Nieznanska H, Nieznanski K, Lukyanetz E, Szewczyk A, Koprowski P. The monomers, oligomers, and fibrils of amyloid- $\beta$ inhibit the activity of mitoBKCa channels by a membrane-mediated mechanism. Biochimica et Biophysica Acta (BBA) - Biomembranes. 2020;1862(9):183337.

20. Kostiuk OP, Korol T, Korol SV, Romanenko SV, Pinchenko $\mathrm{VO}$, Kostiuk PH. Alteration of calcium signaling as one of the mechanisms of Alzheimer's disease and diabetic polyneuropathy. Fiziol Zh. 2010;56(4):130-8.

21. Korol T, Kostiuk OP, Kostiuk PH. Effect of beta-amyloid protein on calcium channels in plasma membranes of cultured hippocampal neurons. Fiziol Zh. 2009;55(4):10-6.
22. Kruchenko ZA, Gorbachenko VA, Chereda IS, Lukyanetz EA. Effect of memantine on motor behavioral phenomena in rats of different ages. Neurophysiology. 2014;46(5):448-51.

23. Tyshchenko Y, Lukyanetz EA. Effects of memantine on behavioral indices of rats in the open field. Neurophysiology. 2017;49(6):453-7.

24. DiTacchio KA, Heinemann SF, Dziewczapolski G. Metformin treatment alters memory function in a mouse model of Alzheimer's disease. J Alzheimers Dis. 2015;44(1):43-8.

25. Tyagi S, Gupta P, Saini AS, Kaushal C, Sharma S. The peroxisome proliferator-activated receptor: A family of nuclear receptors role in various diseases. J Adv Pharm Technol Res. 2011;2(4):236-40.

26. Berger J, Moller DE. The mechanisms of action of PPARs. Annu Rev Med. 2002;53:409-35.

27. Nierenberg AA, Ghaznavi SA, Sande Mathias I, Ellard KK, Janos JA, Sylvia LG. Peroxisome Proliferatoractivated receptor gamma coactivator-1 alpha as a novel target for bipolar disorder and other neuropsychiatric disorders. Biol Psychiat. 2018;83(9):761-9.

Received 27.10.2020 